\title{
In vitro culture of sweet basil: gas exchanges, growth, and rosmarinic acid production
}

\author{
C. KIFERLE ${ }^{1}$, M. LUCCHESINI ${ }^{1}$, R. MAGGINI ${ }^{1}$, A. PARDOSSI ${ }^{1}$, and A. MENSUALI-SODI ${ }^{2}$ \\ Department of Agriculture, Food and Environment, University of Pisa, I-56124 Pisa, Italy ${ }^{1}$ \\ Life Science Institute, Scuola Superiore Sant'Anna, I-56127 Pisa, Italy ${ }^{2}$
}

\begin{abstract}
Five in vitro culture systems with different ventilation rates were used to investigate the influence of vessel environment on photosynthesis, dark respiration, ethylene evolution, and rosmarinic acid (RA) production in sweet basil (Ocimum basilicum L.) micropropagated shoots. The systems under comparison were two bioreactors with either temporary $\left(\right.$ RITA $\left.^{\mathrm{TM}}\right)$ or stationary (Growtek $\left.{ }^{\mathrm{TM}}\right)$ immersion, and three types of vessels (Magenta ${ }^{\mathrm{TM}}$, Microbox $\mathrm{ECO}_{2}^{\mathrm{TM}}$, and $\left.P C C V 25^{\mathrm{TM}}\right)$ that are largely used for plant micropropagation. Shoots of green-leaved cv. Genovese and purple-leaved cv. Dark Opal were cultured on a modified Murashige and Skoog medium containing $0.25 \mathrm{mg} \mathrm{dm}^{-3}$ 6-benzylaminopurine. The instantaneous rates of photosynthesis, dark respiration, and ethylene production were determined by gas chromatography measuring $\mathrm{CO}_{2}$ and ethylene concentrations in vessel headspaces. The tissue RA content was determined by HPLC in HCl-methanol extracts. The explant growth and morphology were significantly affected by culture conditions and cultivars. The largest biomass production was observed under the photomixotrophic culture conditions provided by Growtek $^{\mathrm{TM}}$, whereas the highest RA content in shoot tissues was found in the RITA ${ }^{\mathrm{TM}}$ photomixotrophic system, where ethylene accumulated to the greatest extent.
\end{abstract}

Additional key words: bioreactors, ethylene, mixotrophic culture, photosynthetetic rate, respiration rate, secondary metabolism.

\section{Introduction}

Sweet basil (Ocimum basilicum L.) belonging to the Lamiaceae family, is widely used as food flavouring agent and is cultivated all over the world (Makri and Kintzios 2007). This species is also used for cosmetic and pharmaceutic products as it contains large amounts of essential oils and rosmarinic acid (RA) (Jayasinghe et al. 2003, Petersen and Simmons 2003, Juliani et al. 2008).

Aromatic and medicinal plants, including sweet basil, are usually cultivated in open field which results in large year-to-year variability in both biomass production and the content of active principles (Bourgaud et al. 2001). For this reason, there is an increasing interest for in vitro cell and tissue cultures (Matkowski 2008, Karuppusamy 2009). The in vitro system is characterized by a strict control of the growing conditions and allows to obtain the all-year round production of uniform and high-quality plant material (Lucchesini and Mensuali-Sodi 2010). The possibility to obtain a high RA accumulation has been proven in different in vitro cultured species, such as Lavandula vera, Coleus blumei, and Salvia officinalis
(Matkowski 2008, Park et al. 2008). Different basil species accumulate larger quantities of RA in cells, callus, hairy roots, and micropropagated shoots than in vivo plants (Kintzios et al. 2003, 2004, Rady and Nazif 2005, Hakkim et al. 2007, Kiferle et al. 2011).

Identifying and understanding the effects of in vitro environment on explant growth and secondary metabolism is essential for scaling-up the bioactive compound production by plant cell and tissue cultures (Georgiev et al. 2009). The conventional in vitro cultures are usually photomixotrophic: plantlets use both photosynthates and exogenous sugars as energy sources (Kozai 1991, Kozai and Kubota 2005, Xiao et.al. 2011, Dias et al. 2013). Plantlets with the increased photosynthetic rate $\left(\mathrm{P}_{\mathrm{N}}\right)$ grow and develop better than those with low $\mathrm{P}_{\mathrm{N}}$ (Lucchesini et al. 2001, Afreen et al. 2002, Xiao et al. 2011). The supply of $\mathrm{CO}_{2}$ from external atmosphere is facilitated in vessels with a high ventilation rate which also reduces the accumulation of ethylene synthesized by plant tissues and/or released by

Submitted 13 November 2013, last revision 1 February 2014, accepted 20 March 2014.

Abbreviations: CAD - caffeic acid derivative; $\mathrm{P}_{\mathrm{N}}$ - net phothosynthetic rate; PPFD - photosynthetic photon flux density; $\mathrm{RA}$ - rosmarinic acid; $\mathrm{R}_{\mathrm{D}}$ - dark respiration rate

* Corresponding author present address: Department of Agriculture, Food and Environment, University of Pisa, 56124 Pisa, Italy; fax: +390502216524, e-mail: mariella.lucchesini@unipi.it 
abiotic sources, such as agar and plastic materials (Panizza et al. 1993, Xiao et al. 2011). A high ethylene concentration can influence plantlet morphogenesis and induce chlorophyll breakdown, thus affecting negatively their photosynthesis (Hazarika 2006). Many studies have been conducted to investigate the influence of ethylene and $\mathrm{CO}_{2}$ concentrations in vessel atmosphere on growth and development of in vitro plantlets (Hazarika 2006, Xiao et al. 2011). However, much less attention has been paid to the effects of gas exchange on the production of secondary metabolites (Ikemeyer et al. 1989, Zobayed and Saxena 2004, Mosaleeyanon et al. 2005) and, to our knowledge, no paper focused on the RA production.

In this study, five in vitro culture systems differing in ventilation rates and physical properties of growing medium (solid or liquid) were used to investigate their influence on photosynthesis, dark respiration, ethylene accumulation and RA production in micropropagated shoots of two sweet basil genotypes differing in leaf pigmentation and RA content (Kiferle et al. 2011). The systems under comparison were two bioreactors with either temporary $\left(\right.$ RITA $\left.^{\mathrm{TM}}\right)$ or stationary (Growtek ${ }^{\mathrm{TM}}$ ) immersion and three types of vessels (Magenta $^{\mathrm{TM}}$, Microbox $\mathrm{ECO}_{2}{ }^{\mathrm{TM}}$, and $P C C V 25^{\mathrm{TM}}$ ) largely used for plant micropropagation (Fig. 1, Table 1).

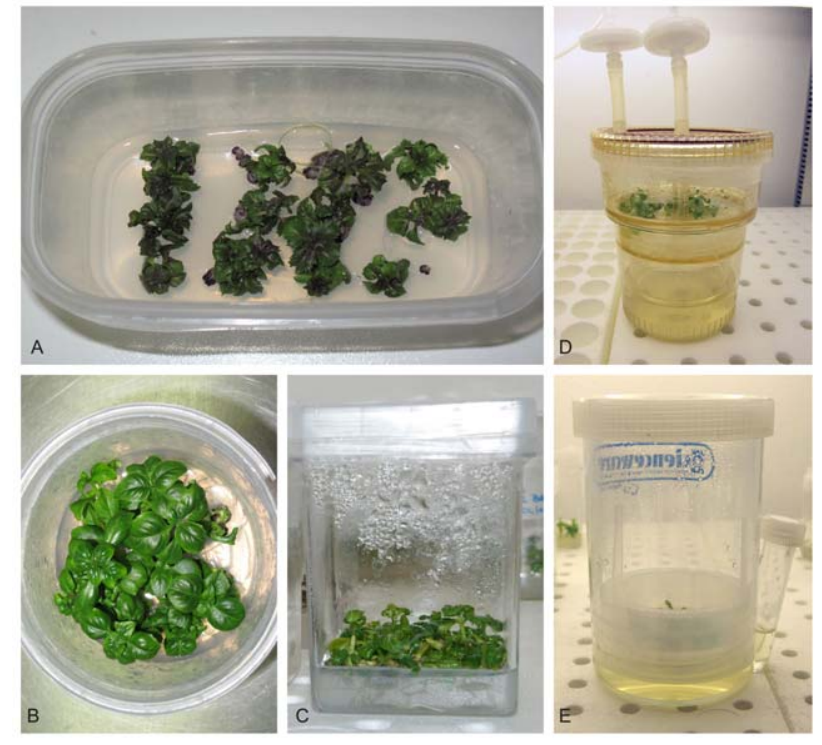

Fig. 1. Types of vessels used for the in vitro culture of sweet basil shoots: $A$ - MicroboxECO${ }_{2}^{\mathrm{TM}}, B-P C C V 25^{\mathrm{TM}}, C-G A-7$ box Magenta $^{\mathrm{TM}}, D$ - temporary immersion system RITA ${ }^{\mathrm{TM}}$, $E$ - cylindrical bioreactor Growtek ${ }^{\mathrm{TM}}$.

Table 1. Main characteristics of culture vessels and growing media used for the in vitro culture of sweet basil from nodal explants. The number of explants per vessel and the air exchange rate are also shown. The headspace volume was calculated as the difference between the total volume and the volume of growing medium. PSU - polysulfonate, PP - polypropylene, PC - polycarbonate, $\varnothing$ - diameter, L - length, W - width, H - height, E - the number of gas exchanges of the vessel per hour.

\begin{tabular}{|c|c|c|c|c|c|c|c|c|}
\hline Vessel type & Supplier & Material & Size $[\mathrm{mm}]$ & $\begin{array}{l}\text { Medium } \\
{\left[\mathrm{dm}^{3}\right]}\end{array}$ & $\begin{array}{l}\text { Headspace } \\
{\left[\mathrm{dm}^{3}\right]}\end{array}$ & $\begin{array}{l}\text { Medium } \\
\text { status }\end{array}$ & $\begin{array}{l}\text { Explant } \\
\text { number }\end{array}$ & $E\left[h^{-1}\right]$ \\
\hline$E C O_{2}{ }^{\mathrm{TM}}$ & $\begin{array}{l}\text { Duchefa Micropoli, } \\
\text { Cesano Boscone, Italy }\end{array}$ & PP & $\begin{array}{l}\mathrm{L}: 125 \\
\mathrm{~W}: 65 \\
\mathrm{H}: 80\end{array}$ & 0.100 & 0.450 & solid & 12 & 7.1 \\
\hline$P C C V 25^{\mathrm{TM}}$ & $\begin{array}{l}\text { TQPL Company, } \\
\text { New Milton, UK }\end{array}$ & PP & $\begin{array}{l}\varnothing: 90 \\
\mathrm{H}: 70\end{array}$ & 0.050 & 0.092 & solid & 6 & 4.2 \\
\hline Magenta $^{\mathrm{TM}}$ & $\begin{array}{l}\text { Sigma Aldrich, } \\
\text { Milan, Italy }\end{array}$ & $\mathrm{PC}$ & $\begin{array}{l}\text { L: } 77 \\
\text { W: } 77 \\
\text { H: } 97\end{array}$ & 0.050 & 0.525 & solid & 6 & 0.7 \\
\hline Growtek $^{\mathrm{TM}}$ & $\begin{array}{l}\text { Scienceware, } \\
\text { Wayne, USA }\end{array}$ & $\mathrm{PC}+\mathrm{PP}$ & $\begin{array}{l}\varnothing: 11 \\
\mathrm{H}: 160\end{array}$ & 0.150 & 1.028 & liquid & 12 & 1.0 \\
\hline RITATM $^{\mathrm{TM}}$ & $\begin{array}{l}\text { Vitropic, Saint-Mathieu- } \\
\text { de-Tréviers, France }\end{array}$ & PSU & $\begin{array}{l}\varnothing: 18 \\
H: 150\end{array}$ & 0.150 & 0.830 & liquid & 12 & 2.0 \\
\hline
\end{tabular}

\section{Materials and methods}

Seeds of two sweet basil (Ocimum basilicum L.) cultivars, green-leaved Genovese (GE) and purple-leaved Dark Opal (DO), purchased from SAIS (Cesena, Italy) were germinated and then grown in hydroponics (floating system). Nodal segments were used as explants and cultured in vitro as previously described (Kiferle et al. 2011). Basil shoots were proliferated in PCCV25 boxes (six explants per box) on a solid $\left(7 \mathrm{~g} \mathrm{dm}^{-3}\right.$ of Difco Bacto agar) Murashige and Skoog (1962; MS) medium with $300 \mathrm{mg} \mathrm{dm}^{-3}$ reduced glutathione (GSH),
$500 \mathrm{mg} \mathrm{dm} \mathrm{dm}^{-3}$ 2-(N-morpholino) ethanesulfonic acid (MES), $30 \mathrm{~g} \mathrm{dm}^{-3}$ sucrose, and $0.25 \mathrm{mg} \mathrm{dm}^{-3}$ 6-benzylamino-purine (BA). The $\mathrm{pH}$ was adjusted to 5.8 before autoclaving. From these stock cultures, explants were excised and sub-cultured in different types of vessels on either a solid or liquid medium with the same nutrient composition as previously described. Magenta ${ }^{\mathrm{TM}}$, Microbox $\mathrm{ECO}_{2}{ }^{\mathrm{TM}}$, and $\mathrm{PCCV} 25^{\mathrm{TM}}$ vessels were filled with the solid medium and equipped with a filter on their closures in order to ensure aseptic ventilation. RITA ${ }^{\mathrm{TM}}$ 
and Growtek ${ }^{\mathrm{TM}}$ bioreactors were employed for temporary and stationary immersion cultures, respectively. In RITA $^{\mathrm{TM}}$ system, an air pump was used to push the liquid medium up and immerse temporarily the explants $(1 \mathrm{~min}$ every $12 \mathrm{~h}$ ). The air pressure was applied through $0.2 \mu \mathrm{m}$ porous filters. Growtek ${ }^{\mathrm{TM}}$ was modified by fitting a round filter (a diameter of $19 \mathrm{~mm}$ ) to the side tube for sterile ventilation. All culture vessels were equipped with a gassampling device to allow the analysis of headspace air (Lucchesini et al. 2001). The hourly number of gas exchanges (E) in each type of vessel was determined using ethylene as tracer gas. The cultures were incubated in a growth chamber at a temperature of $22 \pm 1{ }^{\circ} \mathrm{C}$, a $16-\mathrm{h}$ photoperiod, and an irradiance of $100 \mu \mathrm{mol} \mathrm{m}^{-2} \mathrm{~s}^{-1}$.

The fresh and dry masses were determined at the onset of the culture (0) and after 14, 21, and $28 \mathrm{~d}$ of culture, whereas the shoot height, leaf number, and tissue content of chlorophylls, anthocyanins, and RA were determined at the end of the experiment ( $28^{\text {th }}$ day). Gas samplings were taken from the head-space of the culture vessels 14,21 , and $28 \mathrm{~d}$ after the onset of culture and analyzed for $\mathrm{CO}_{2}$ and ethylene concentrations. Three $2-\mathrm{cm}^{3}$ air samples were consecutively withdrawn with a hypodermic syringe (three replicates, each consisting of an individual vessel). Air samples were collected at the end of the dark period and at the $1^{\text {st }}, 3^{\text {rd }}, 6^{\text {th }}$, and $8^{\text {th }}$ hour of the photoperiod; the ethylene concentration was determined in air samples collected at the $6^{\text {th }}$ hour of the photoperiod.

The ethylene and $\mathrm{CO}_{2}$ concentrations were measured using an HP 6890 gas chromatograph (Hewlett Packard, Milan, Italy) equipped with a stainless steel column (1.5 m length and $0.04 \mathrm{~m}$ i.d.) packed with HaySep ${ }^{\circledR} T$ (Agilent Technologies, Milan, Italy), a flame ionization detector (ethylene determination) and a thermal conductivity detector $\left(\mathrm{CO}_{2}\right.$ determination). Column and detector temperatures were 70 and $350{ }^{\circ} \mathrm{C}$ (the ethylene analysis) or 70 and $200{ }^{\circ} \mathrm{C}$ (the $\mathrm{CO}_{2}$ analysis). Nitrogen was used as carrier gas at a flow rate of $30 \mathrm{~cm}^{3} \mathrm{~min}^{-1}$ and as reference gas at $15 \mathrm{~cm}^{3} \mathrm{~min}^{-1}$ for a thermal conductivity detector. The instantaneous $\mathrm{P}_{\mathrm{N}}$ was determined as reported by Fujiwara et al. (1987): $\mathrm{P}_{\mathrm{N}}=$ $\left(\mathrm{CO}_{2 \text { in }}-\mathrm{CO}_{2 \text { out }}\right)_{t} \times \mathrm{K} \times \mathrm{E} \times \mathrm{V} /$ d.m., where $\left(\mathrm{CO}_{2 \text { in }}-\mathrm{CO}_{2 \text { out }}\right)$ is the difference between $\mathrm{CO}_{2}$ concentration $\left[\mathrm{cm}^{3} \mathrm{~m}^{-3}\right]$ inside and outside the culture vessel at time $t, \mathrm{~K}$ is the molar conversion factor $\left[41 \times 10^{-3} \mu \mathrm{mol} \mathrm{dm}{ }^{-3}\right], \mathrm{V}\left[\mathrm{dm}^{3}\right]$ is the headspace volume, $\mathrm{E}$ is the number of hourly gas exchanges (Table 1) of the vessel and d.m. [g] the shoot dry mass per culture vessel. The equation can be used for the estimation of dark respiration $\left(\mathrm{R}_{\mathrm{D}}\right)$. In similar way, the rate of ethylene $\left(\mathrm{C}_{2} \mathrm{H}_{4}\right)$ release from the culture [pmol $\mathrm{g}^{-1}$ (d.m.) $\mathrm{s}^{-1}$ ] was calculated as follows: $\mathrm{C}_{2} \mathrm{H}_{4}$ production $=$ $\left(\mathrm{C}_{2} \mathrm{H}_{4 \text { in }}-\mathrm{C}_{2} \mathrm{H}_{4 \text { out }}\right)_{t} \times \mathrm{K} \times \mathrm{E} \times \mathrm{V} /$ d.m., where $\mathrm{C}_{2} \mathrm{H}_{4 \text { in }}$ is the ethylene concentration $\left[\mathrm{mm}^{3} \mathrm{~m}^{-3}\right]$ inside the vessels at the time $t$ and $\mathrm{C}_{2} \mathrm{H}_{4 \text { out }}=0$, taking into account that ethylene is present in a negligible concentration in the atmosphere outside the vessel. Moreover, the production of ethylene from the vessels with the solid medium in the absence of plants was subtracted from the measured values to exclude an abiotic contribution to the ethylene production (Mensuali-Sodi et al. 1992).

The content of chlorophylls $\left[\mathrm{mg} \mathrm{g}^{-1}\right.$ (f.m.) $]$ and anthocyanins [mg(cyanidin-3-glucoside) $\mathrm{g}^{-1}$ (d.m.)] were determined spectrophotometrically in shoot samples that were extracted by the mixture of $95 \%(\mathrm{v} / \mathrm{v})$ ethanol and $80 \%(\mathrm{v} / \mathrm{v})$ methanol with $1.2 \mathrm{M} \mathrm{HCl}$, respectively, in the dark at $4{ }^{\circ} \mathrm{C}$ overnight (Kiferle et al. 2011).

The content of RA and other caffeic acid derivatives (CADs; e.i., caffeic acid, caftaric acid, chlorogenic acid, cicoric acid, cynarin, ferulic acid, $t$-cinnamic acid, and $p$-coumaric acid) were determined in samples consisting of one or two shoots from the same vessel. All the samples were rapidly washed in tap water, rinsed in deionised water, gently dried, frozen in liquid nitrogen, and stored at $-80{ }^{\circ} \mathrm{C}$ before analyses which were performed within a few weeks after sampling. The samples were not dried in an oven, as desiccation prior to extraction was found to reduce markedly the RA content of sweet basil tissues (Kiferle et al. 2011). The content of RA and selected CADs in the HCl-methanol extracts was determined by HPLC as previously described (Kiferle et al. 2011) and expressed on a dry mass unit (the dry mass content was determined in sub-samples). Peak identification was accomplished with mass spectrometry (LCMS) and tandem mass spectrometry (LC-MS-MS) as previously reported (Kiferle et al. 2011). The detection limit of the analytical method was $0.05 \mathrm{mg} \mathrm{g}^{-1}$ (d.m.).

A completely randomized design was adopted. Data were subjected to $A N O V A$ and mean values were separated using the LSD test at the $5 \%$ probability level. The statistical analysis was performed using the Statgraphics Centurion XV.II (Manugistic Co., Rockville, USA) software. The experiment was repeated twice with similar findings and the paper reports the results from a representative run.

\section{Results}

During the dark period, the headspace concentration of $\mathrm{CO}_{2}$ ranged between 1000 and $3000 \mathrm{~cm}^{3} \mathrm{~m}^{-3}$ in all the types of vessels with GE shoots except for the basil plantlets cultured into the $P C C V^{\mathrm{TM}}$ vessel, where the $\mathrm{CO}_{2}$ concentration rised up to $4000 \mathrm{~cm}^{3} \mathrm{~m}^{-3}$ at the end of the culture (Fig. 2A). DO plantlets showed similar $\mathrm{CO}_{2}$

values also in RITA $^{\mathrm{TM}}$ vessels (Fig. $2 B$ ). During daytime, all the solid cultures showed $\mathrm{CO}_{2}$ concentrations below $500 \mathrm{~cm}^{3} \mathrm{~m}^{-3}$, whereas in Growtek ${ }^{\mathrm{TM}}$ and RITA bioreactors, the $\mathrm{CO}_{2}$ concentrations were similar to those determined at the end of the night period (Fig. $2 C, D$ ). The highest $\mathrm{CO}_{2}$ concentration was recorded in the DO 
plantlets cultured in RITA ${ }^{\mathrm{TM}}$ system (Fig. 2D). The $\mathrm{CO}_{2}$ concentration in the headspace depended on the plantlet $\mathrm{P}_{\mathrm{N}}$ and $\mathrm{R}_{\mathrm{D}}$ (Fig. 3). At the end of the dark phase (Fig. 3A,B), high $\mathrm{R}_{\mathrm{D}}$ values were observed in Magenta ${ }^{\mathrm{TM}}$, $P C C V 25^{\mathrm{TM}}$, and especially in Microbox $\mathrm{ECO}_{2}^{\mathrm{TM}}$. The plantlets cultured in these vessels showed the highest $\mathrm{CO}_{2}$ uptake during the light period (Fig. $3 C, D$ ). The $\mathrm{CO}_{2}$ uptake in these cultures was evident just after one hour from the onset of photoperiod and showed constant values from the $3^{\text {rd }}$ until the $8^{\text {th }}$ hour (data not shown). The $\mathrm{P}_{\mathrm{N}}$ (Fig. $3 \quad C, D$ ) increased with an increased gas exchange characterized by E value (Table 1). Basil shoots grown in Microbox $\operatorname{ECO}_{2}^{\mathrm{TM}}\left(\mathrm{E}=7.1 \mathrm{~h}^{-1}\right)$ exhibited the highest $\mathrm{P}_{\mathrm{N}}$ during the whole culture period, whereas the lowest $\mathrm{P}_{\mathrm{N}}$ was generally found in Magenta ${ }^{\mathrm{TM}}\left(\mathrm{E}=0.7 \mathrm{~h}^{-1}\right)$. The values of both $\mathrm{R}_{\mathrm{D}}$ and $\mathrm{P}_{\mathrm{N}}$ were very low in the explants grown in RITA $^{\mathrm{TM}}$ and Growtek $^{\mathrm{TM}}$ bioreactors (Fig. 3).

Analogous trends in terms of $R_{D}$ and $P_{N}$ were observed in both the sweet basil cultivars. By the way, the GE plantlets in Magenta ${ }^{\mathrm{TM}}$, Microbox $\mathrm{ECO}_{2}{ }^{\mathrm{TM}}$, and $P C C V 25^{\mathrm{TM}}$ showed higher $\mathrm{P}_{\mathrm{N}}$ values than the $\mathrm{DO}$

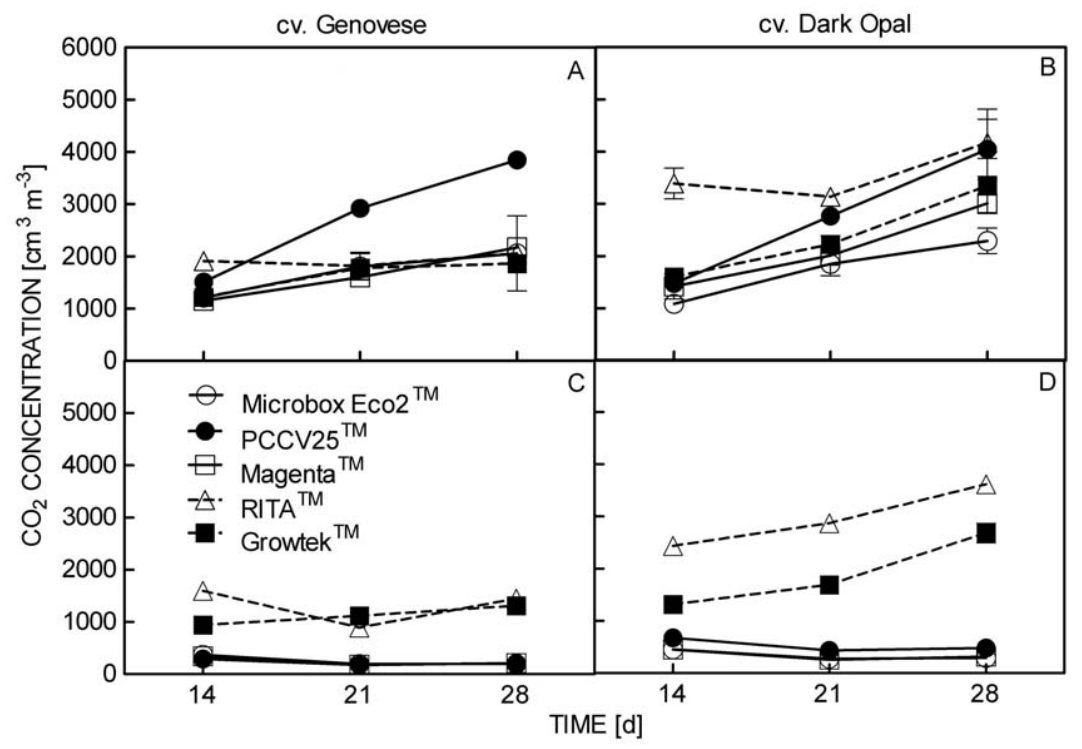

Fig. 2. The concentration of $\mathrm{CO}_{2}$ in headspace of different culture vessels used for the in vitro cultivation for 14,21 , and $28 \mathrm{~d}$ of sweet basil shoots with green (cv. Genovese) or purple (cv. Dark Opal) leaves. The measurements were performed at the end of dark period $(A, B)$ and during the daytime (average values of the $3^{\text {rd }}, 6^{\text {th }}$ and $8^{\text {th }}$ hourof the photoperiod; $C, D$ ). Means $\pm \mathrm{SE}, n=3$.

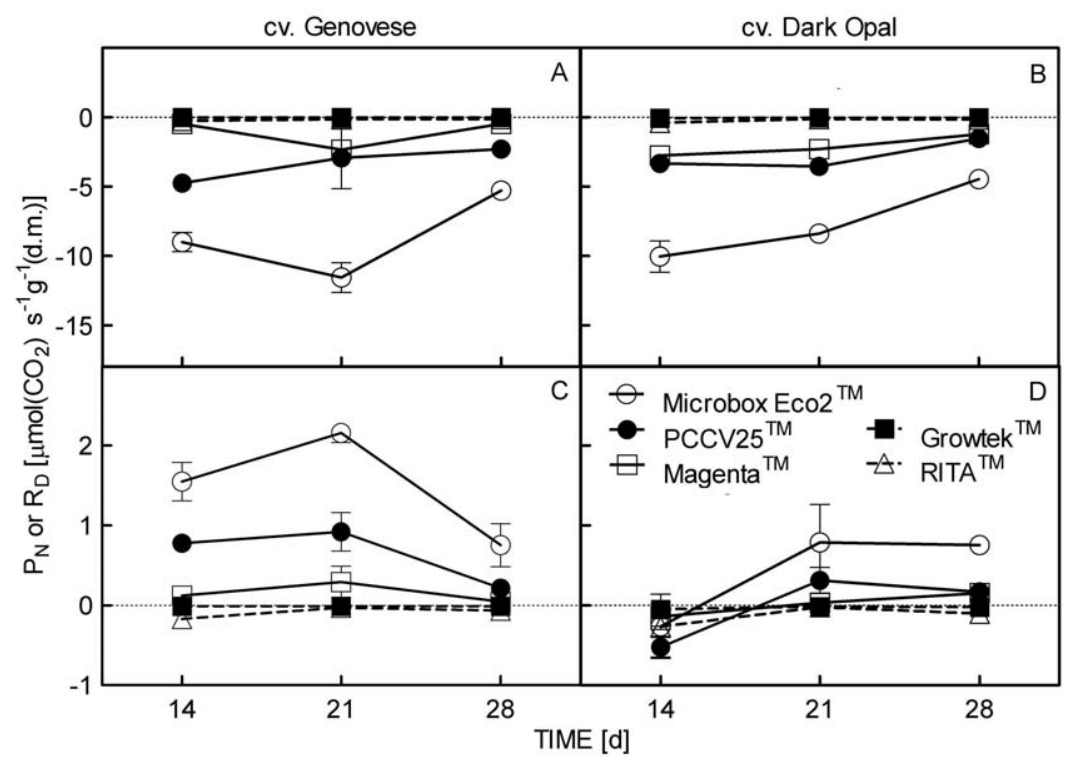

Fig. 3. The dark respiration rate $\left(\mathrm{R}_{\mathrm{D}}\right)$ and net photosynthetic rate $\left(\mathrm{P}_{\mathrm{N}}\right)$ in shoots of two sweet basil cultivars with green (Genovese) or purple (Dark Opal) leaves cultured in vitro for 14, 21, and $28 \mathrm{~d}$ using different types of vessels. The measurements were performed at the end of dark period $(A, B)$ and during the daytime (average values of the $3^{\text {rd }}, 6^{\text {th }}$ and $8^{\text {th }}$ hourof the photoperiod; $C, D$ ). Means $\pm \mathrm{SE}, n=3$. 
plantlets and acquired photosynthetic competence earlier than DO. In fact, a photosynthetic activity was evident after 14 or $21 \mathrm{~d}$ of culture in the GE and DO explants, respectively (Fig. 3C,D).

In the GE culture, the ethylene concentration in the vessel headspace (Fig. 4A) remained rather constant during the experiment regardless of the vessel type. In RITA $^{\mathrm{TM}}$ bioreactor, the ethylene concentration was always significantly higher than in the other vessels (Fig. 4A). The ethylene concentration in the DO cultures showed a sharp increase only in $R I T A^{\mathrm{TM}}$ bioreactor after $21 \mathrm{~d}$ of culture (Fig. $4 B$ ). The rate of ethylene production from shoots of both the cultivars decreased gradually with time (Fig. 4C,D) except for $\mathrm{DO}$ in $R I T A^{\mathrm{TM}}$ that showed an increase after day 21. At the end of culture, the highest rate of ethylene production was determined in RITA ${ }^{\mathrm{TM}}$ bioreactors (Fig. $4 C, D$ ).

The longest shoots were observed in Magenta ${ }^{\mathrm{TM}}$ and RITA $^{\mathrm{TM}}$ for GE, and in PCCV $V^{\mathrm{TM}}$ for DO (Table 2). The greatest number of leaves was recorded in the GE shoots cultured in $P C C V^{\mathrm{TM}}$, whereas in $\mathrm{DO}$, the lowest number of leaves was observed in the two bioreactors (Table 2). The shoot number per plantlet was quite low (it averaged 2.09) with no significant differences between the cultivars and among the vessel types (Table 2). The vessel type influenced significantly the accumulation of fresh and dry masses, but they were not affected by plant genotype (Table 2). In both the genotypes, the highest

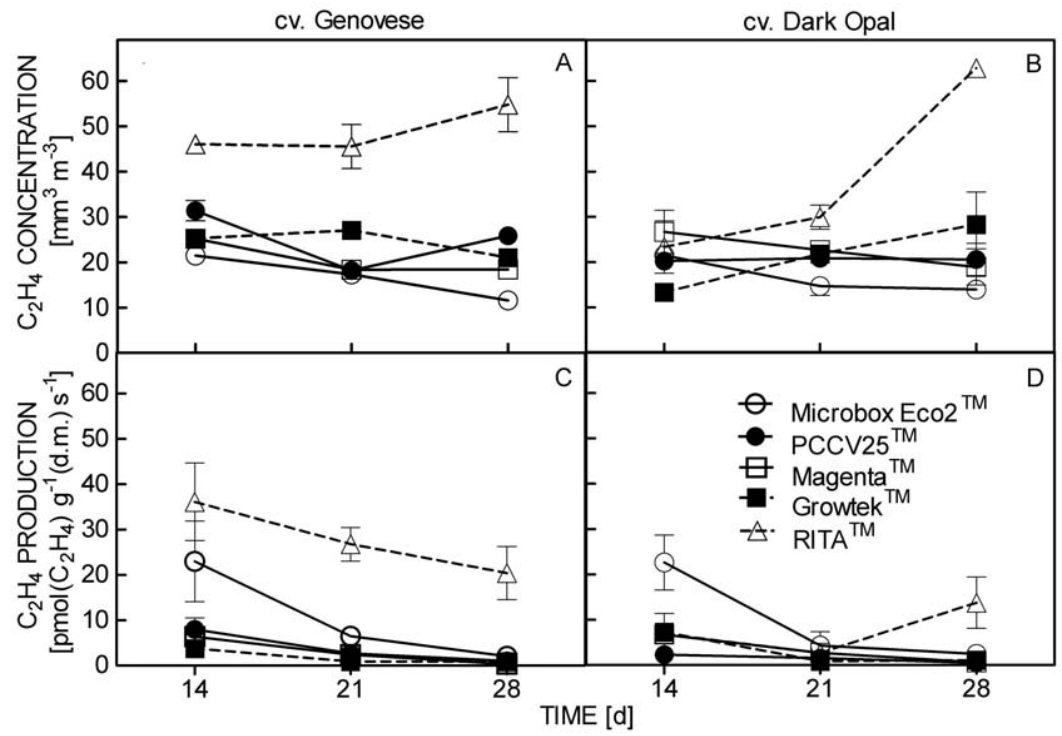

Fig. 4. The ethylene $\left(\mathrm{C}_{2} \mathrm{H}_{4}\right)$ concentration in headspace at the $6^{\text {th }}$ hour of photoperiod and the ethylene production in shoots of two sweet basil cultivars with green (Genovese) or purple (Dark Opal) leaves cultured in vitro for 14, 21, and $28 \mathrm{~d}$ using different types of vessels. Means $\pm \mathrm{SE}, n=3$.

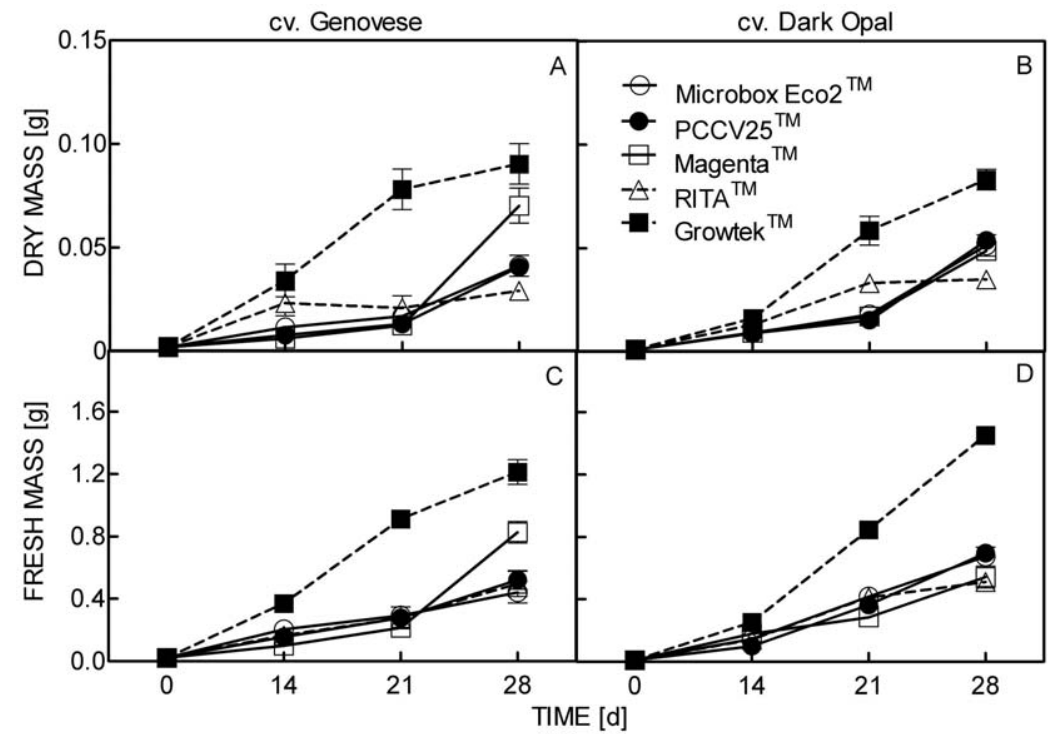

Fig. 5. The time courses of dry and fresh masses in shoots of two sweet basil cultivars with green (Genovese) or purple (Dark Opal) leaves cultured in vitro using different types of vessels. Means $\pm \mathrm{SE}, n=3$. 
fresh and dry masses were observed in Growtek ${ }^{\mathrm{TM}}$ (Fig. 5; Table 2). Moreover, the initial shoot fresh mass of GE and DO were 22 and $11 \mathrm{mg}$, respectively, and the shoot dry mass 1.9 and $0.9 \mathrm{mg}$. Shoot masses increased till the end of cultivation in all the vessels apart from the RITA ${ }^{\mathrm{TM}}$ system, where shoot growth stopped after 14 or $21 \mathrm{~d}$ of culture of GE and DO, respectively (Fig. 5).

The shoot chlorophyll content was similar in the DO and GE plantlets and was higher in shoots cultured on the solid medium than in those cultured in the liquid medium (Table 2). As expected, the DO explants contained much more anthocyanins than GE (Table 2). The vessel type did not influence the content of these pigments in the GE shoots. In contrast, the use of Growtek ${ }^{\mathrm{TM}}$ bioreactors reduced considerably the content of anthocyanins in DO. In these cultures, anthocyanins appeared to accumulate in the callus that developed at the base of the explants (Fig. 6F), whereas leaves did not show any reddish colour. Callus formation was not observed in the other vessels. The leaves of the GE plantlets maintained their typical oval shape and a dark green colour (Fig. 6A, B,C). The red leaves of DO showed a tendency to greening (Fig. 6E,F) in comparison to the in vivo plants (Fig. 6D). Some morphological alterations were also observed in the DO plantlets grown in Growtek ${ }^{\mathrm{TM}}$, as they did not exhibit the typical ruffled edge and showed hyperhydricity symptoms (Fig. $6 F$ ).

Among the CADs of interest, RA was the only compound found in all samples at concentrations higher than a detection limit. At the end of the culture period, the content of RA was significantly higher in the shoots grown in RITA ${ }^{\mathrm{TM}}$ compared to all the other vessel types (Fig. 7). Moreover, in this type of vessel, the GE and DO cultures showed a significant difference in the RA content: 154.8 and $100.2 \mathrm{mg} \mathrm{g}^{-1}$ (d.m.), respectively. No significant differences were evident in the RA content in all the other vessels, averaging $44 \mathrm{mg} \mathrm{g}^{-1}$ (d.m.) (Fig. 7).
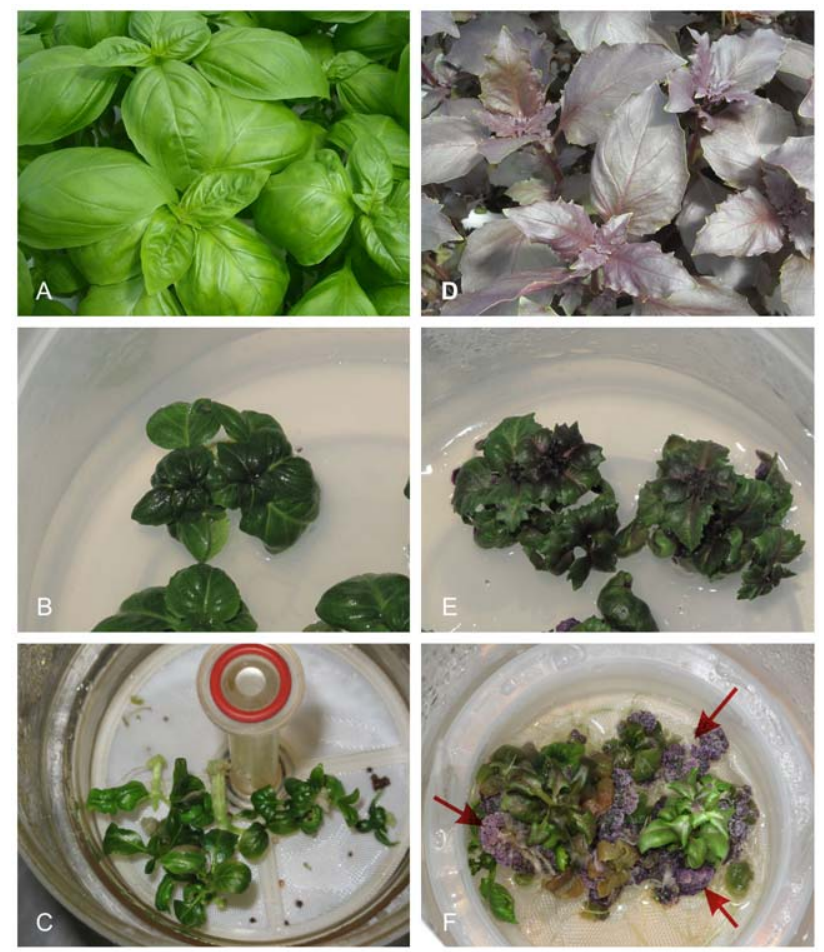

Fig. 6. The in vitro shoot culture of two sweet basil cultivars with green (Genovese; $A, B, C$ ) or purple (Dark Opal, $D, E, F$ ) leaves and in different types of vessels: $P C C V^{\mathrm{TM}}(B, E), R I T A^{\mathrm{TM}}$ $(C)$, or Growtek ${ }^{\mathrm{TM}}(F)$. The pictures were taken at the end of multiplication phase. Arrows in $F$ show the conspicuous red callus masses.

Table 2. The shoot length $\left(\mathrm{S}_{\mathrm{L}}\right)$ [cm], leaf number $\left(\mathrm{L}_{\mathrm{N}}\right)$, shoot number $\left(\mathrm{S}_{\mathrm{N}}\right)$, shoot fresh mass $\left(\mathrm{S}_{\mathrm{FM}}\right)$ [g], shoot dry mass $\left(\mathrm{S}_{\mathrm{DM}}\right)$ [g], and total chlorophyll (Chl) $\left[\mathrm{mg} \mathrm{g}^{-1}\right.$ (f.m.) $]$ and anthocyanin (Anth) $\left[\mathrm{mg} \mathrm{g}^{-1}\right.$ (d.m.) $]$ content in shoots of sweet basil cvs. Genovese and Dark Opal cultured in vitro for $28 \mathrm{~d}$ using different types of vessels. Data were subjected to ANOVA $(* * P \leq 0.01 ; * * * P \leq 0.001 ;$ n.s. $=$ not significant) and mean values $(n=12)$ were separated using the LSD test: mean values followed by different letters differ significantly $(P \leq 0.05)$.

\begin{tabular}{|c|c|c|c|c|c|c|c|c|}
\hline Cultivar & Vessel type & $\mathrm{S}_{\mathrm{L}}$ & $\mathrm{L}_{\mathrm{N}}$ & $\mathrm{S}_{\mathrm{N}}$ & $\mathrm{S}_{\mathrm{FM}}$ & $\mathrm{S}_{\mathrm{DM}}$ & Chl & Anth \\
\hline Genovese & $\begin{array}{l}\text { ECO2 } 2^{\mathrm{TM}} \\
\text { PCCV25 } \\
\text { Magenta }^{\mathrm{TM}} \\
\text { Growtek }^{\mathrm{TM}} \\
\text { RITA }^{\mathrm{TM}}\end{array}$ & $\begin{array}{l}0.87 \mathrm{~b} \\
1.37 \mathrm{ab} \\
2.00 \mathrm{a} \\
1.28 \mathrm{~b} \\
2.00 \mathrm{a}\end{array}$ & $\begin{array}{r}9.5 \mathrm{~b} \\
12.3 \mathrm{a} \\
9.5 \mathrm{~b} \\
7.8 \mathrm{~b} \\
7.0 \mathrm{~b}\end{array}$ & $\begin{array}{l}1.92 \mathrm{a} \\
2.25 \mathrm{a} \\
2.33 \mathrm{a} \\
2.00 \mathrm{a} \\
2.25 \mathrm{a}\end{array}$ & $\begin{array}{l}0.442 \mathrm{~b} \\
0.522 \mathrm{~b} \\
0.826 \mathrm{~b} \\
1.212 \mathrm{a} \\
0.507 \mathrm{~b}\end{array}$ & $\begin{array}{l}0.035 \mathrm{~cd} \\
0.035 \mathrm{~cd} \\
0.070 \mathrm{~b} \\
0.090 \mathrm{a} \\
0.029 \mathrm{c}\end{array}$ & $\begin{array}{l}0.87 \mathrm{~b} \\
1.33 \mathrm{a} \\
0.81 \mathrm{~b} \\
0.25 \mathrm{~cd} \\
0.39 \mathrm{~cd}\end{array}$ & $\begin{array}{l}0.58 \mathrm{~b} \\
0.79 \mathrm{~b} \\
0.48 \mathrm{~b} \\
1.47 \mathrm{~b} \\
0.87 \mathrm{~b}\end{array}$ \\
\hline Dark Opal & $\begin{array}{l}\text { ECO2 } 2^{\mathrm{TM}} \\
\text { PCCV25 } \\
\text { Magenta }^{\mathrm{TM}} \\
\text { Growtek }^{\mathrm{TM}} \\
\text { RITA }^{\mathrm{TM}}\end{array}$ & $\begin{array}{l}1.37 \mathrm{ab} \\
2.04 \mathrm{a} \\
1.25 \mathrm{~b} \\
1.56 \mathrm{ab} \\
1.39 \mathrm{ab}\end{array}$ & $\begin{array}{r}11.6 \mathrm{a} \\
14.3 \mathrm{a} \\
11.3 \mathrm{a} \\
9.3 \mathrm{~b} \\
9.3 \mathrm{~b}\end{array}$ & $\begin{array}{l}2.00 \mathrm{a} \\
2.00 \mathrm{a} \\
2.00 \mathrm{a} \\
2.18 \mathrm{a} \\
2.00 \mathrm{a}\end{array}$ & $\begin{array}{l}0.673 \mathrm{~b} \\
0.697 \mathrm{~b} \\
0.543 \mathrm{~b} \\
1.458 \mathrm{a} \\
0.508 \mathrm{~b}\end{array}$ & $\begin{array}{l}0.050 \mathrm{~b} \\
0.053 \mathrm{bc} \\
0.043 \mathrm{bc} \\
0.083 \mathrm{a} \\
0.035 \mathrm{c}\end{array}$ & $\begin{array}{l}1.31 \mathrm{a} \\
1.60 \mathrm{a} \\
0.57 \mathrm{bc} \\
0.10 \mathrm{~d} \\
0.36 \mathrm{~cd}\end{array}$ & $\begin{array}{c}10.04 \mathrm{ab} \\
20.28 \mathrm{a} \\
19.12 \mathrm{a} \\
1.49 \mathrm{~b} \\
9.25 \mathrm{ab}\end{array}$ \\
\hline $\begin{array}{l}\mathrm{Cv} .(\mathrm{A}) \\
\text { Vessel (B) } \\
\mathrm{A} \times \mathrm{B}\end{array}$ & & $\begin{array}{l}\text { n.s. } \\
* * * \\
\text { n.s. }\end{array}$ & $\begin{array}{l}* * \\
* * * \\
\text { n.s. }\end{array}$ & $\begin{array}{l}\text { n.s. } \\
\text { n.s. } \\
\text { n.s. }\end{array}$ & $\begin{array}{l}\text { n.s. } \\
* * * \\
\text { n.s. }\end{array}$ & $\begin{array}{l}\text { n.s. } \\
* * * \\
*\end{array}$ & $\begin{array}{l}\text { n.s. } \\
* * * \\
* *\end{array}$ & $\begin{array}{l}* * * \\
* * * \\
* * *\end{array}$ \\
\hline
\end{tabular}




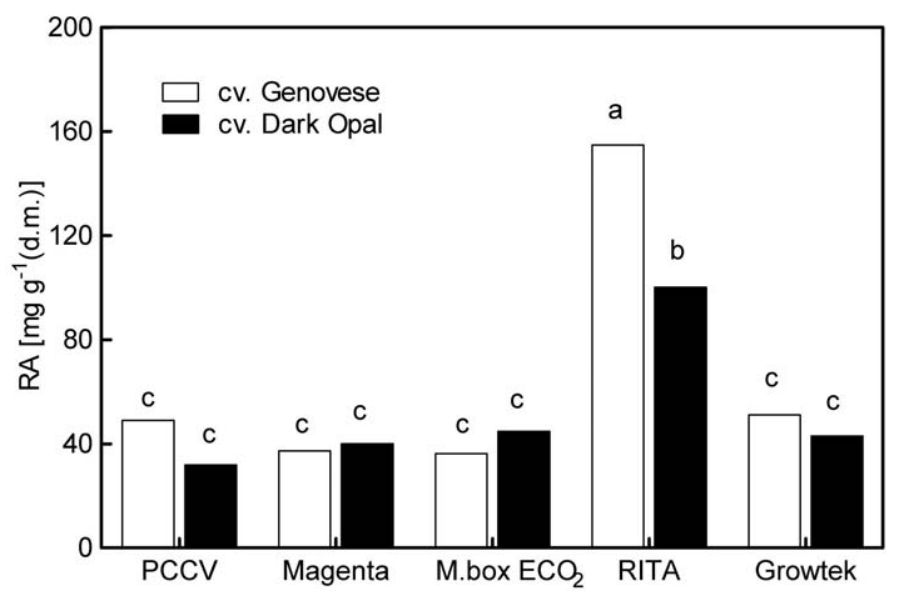

Fig. 7. The rosmarinic acid (RA) content in shoots of two sweet basil cultivars with green (Genovese) or purple (Dark Opal) leaves cultured in vitro using different types of vessels. The measurements were taken after $28 \mathrm{~d}$ of culture. ANOVA was performed and mean values were separated using the LSD test $(n=4)$. Different letters mark significant differences $(P \leq 0.05)$ among vessel types.

\section{Discussion}

In our work, the type of vessel affected all measured growth parameters with the exception of the shoot number. In agreement with previous work (Kiferle et al. 2011), the proliferation aptitude of sweet basil explants was lower in comparison with previous findings in the same species (e.g., Sahoo et al. 1997, Begum et al. 2002). Nevertheless, the adopted micropropagation protocols enabled a large mass production, which was about 80 mg(d.m.) per plantlet at the end of the multiplication phase in Magenta ${ }^{\mathrm{TM}}$ and Growtek ${ }^{\mathrm{TM}}$ (Table 2). Almost a 10 -fold lower biomass production was obtained by Kintzios et al. (2004) from nodal explants of this species in bioreactors. A large biomass production in an in vitro culture may be ascribed to the favorable environmental conditions, in particular to vessel ventilation which can stimulate $\mathrm{P}_{\mathrm{N}}$ reducing the degree of dependence on exogenous sugar (Kozai et al. 2000, Xiao et al. 2011).

In this work, the highest chlorophyll content was found in sweet basil shoots grown on the solid media, whereas the highest $\mathrm{P}_{\mathrm{N}}$ was associated with the highest $\mathrm{E}$ of Microbox $\mathrm{ECO}_{2}^{\mathrm{TM}}$ and $\mathrm{PCCV}^{\mathrm{TM}}$ which were specifically designed to improve vessel aeration. A positive correlation between the degree of aeration in the culture vessels and chlorophyll content was reported by Pospíśilová et al. (2000). In contrast, we observed a negative relationship between $\mathrm{P}_{\mathrm{N}}$ and growth. In fact, the largest dry mass accumulation was observed in Magenta $^{\mathrm{TM}}\left[\mathrm{P}_{\mathrm{N}}=0.15 \mu \mathrm{mol} \mathrm{g}{ }^{-1}\right.$ (f.m.) $\left.\mathrm{s}^{-1}, \mathrm{E}=0.7 \mathrm{~h}^{-1}\right]$ and in Growtek ${ }^{\mathrm{TM}}\left[\mathrm{P}_{\mathrm{N}}=-0.01 \mu \mathrm{mol} \mathrm{g}{ }^{-1}\right.$ (f.m.) $\left.\mathrm{s}^{-1} ; \mathrm{E}=1.0 \mathrm{~h}^{-1}\right]$. In many cases, photomixotrophic conditions can yield better results than photoautotrophic conditions (Hazarika 2006, Lucchesini et al. 2006). We may speculate that in the poorly-ventilated Magenta ${ }^{\mathrm{TM}}$ vessel, the reduction of explant $\mathrm{P}_{\mathrm{N}}$ compared with the other two systems, $P C C V^{\mathrm{TM}}$ and Microbox $E C \mathrm{O}_{2}^{\mathrm{TM}}$, allowed a better utilization of exogenous sugars, thus resulting in a larger mass accumulation. These results are in agreement with those reported by Chanemougasoundharam et al. (2004), who demonstrated that culture systems with low gaspermeable closures increase potato shoot growth.

The use of Growtek ${ }^{\mathrm{TM}}$ stimulated the shoot growth of both the cultivars, but it caused the modification of leaf shape, the proliferation of conspicuous callus mass and the occurrence of hyperhydricity, especially in the DO shoots. The use of a liquid medium offers several advantages for mass propagation but it may cause the occurrence of severe morpho-physiological disorders involving an apoplastic water accumulation due to the continuous immersion of tissue ( $\mathrm{Ziv}$ 2000, Hazarika 2006, Savio et al. 2012). Compared to normal shoots of greenhouse-grown apple plants, the leaves of hyperhydric shoots cultivated in a bioreactor contain less chlorophyll and show a lower ribulose bisphosphate carboxylase activity resulting in reduced carbon assimilation (Chakrabarty et al. 2005). In vitro plants grown in a liquid medium are generally heterotrophic (Jackson 2003). These systems facilitate the sucrose uptake by plantlets in comparison with solid systems (Afreen et al. 2002, Dey 2005). It is known that higher sugar availability can decrease the photosynthetic ability of micropropagated plantlets (Kozai 1991, Lucchesini et al. 2006, Mingozzi et al. 2011). In this work, the basil plantlets, cultured in the liquid medium with sugars, showed a low chlorophyll content and low $\mathrm{P}_{\mathrm{N}}$. Moreover, in RITA $^{\mathrm{TM}}$ and Growtek ${ }^{\mathrm{TM}}$, the temporary or constant submersion of the basil plantlets could alter the function of stomata, thus further affecting negatively their $\mathrm{P}_{\mathrm{N}}$ as found by Afreen et al. (2002).

Dey (2005) reported that Growtek ${ }^{\mathrm{TM}}$ bioreactor facilitates the nutrients uptake by explants of several species due to the presence of a floating explant holder. In this work, the high availability of nutrients could explain the reduction of the anthocyanins content (greening) of the DO explants cultured in Growtek ${ }^{\mathrm{TM}}$, as 
the synthesis of this class of pigments is inversely correlated to the availability of sugars and minerals in the medium (Steyn et al. 2002).

Vessel ventilation determines the whole gas composition of the headspace and can also influence the ethylene concentration (Mensuali-Sodi et al. 2007). In this work, a negative relationship between the ethylene accumulation and $\mathrm{E}$ was observed in all the culture vessels except $R I T A^{\mathrm{TM}}$, where the ethylene concentration in the headspace was affected by the high production of this hormone from the plant tissues. Ethylene is often synthesized by in vitro cultured tissues in response to stress conditions (Morgan and Drew 1997, Gaspar et al. 2002, Yasmin et al. 2013). In the RITA ${ }^{\mathrm{TM}}$ system, sweet basil was exposed to different kinds of stresses: 1) the water accumulation in the apoplast which imposed a low oxygen content (Saher et al. 2004); 2) the transient nutrient starvation due to the temporary immersion (Deng et al. 2012); and 3) shoot stirring during the immersion due to bubbling the medium (Martre et al. 2001). All these stresses could increase ethylene biosynthesis. The ethylene accumulation in the RITA ${ }^{\mathrm{TM}}$ system was associated with a low dry mass, especially of the GE plantlets, but with a high RA content at the end of the culture. Ethylene may either stimulate or inhibit growth (Biddington 1992) and secondary metabolism in various plant tissue and cell cultures. For instance, ethylene promotes the production of alkaloids in cell suspension cultures of Coffea arabica and Thalictrum rugosum (Cho et al. 1988) and of Thalictrum minus (Kobayashi et al. 1991 a,b), and diosgenin in in vitro plantlets of Dioscorea zingiberensis (Diarra et al. 2013). The influence of plant growth regulators on production of secondary metabolites was also demonstrated in other studies (Patnaik et al. 1999, Lucchesini et al. 2009, Kiferle et al. 2011).

In experiments with different sweet basil cultivars, it was observed that in vitro cultured tissues or cells accumulate more secondary metabolites than donor in vivo grown plants (Kiferle et al. 2011, Bertoli et al. 2013). This may be ascribed to peculiar environmental conditions provided by the in vitro culture since in vivo sweet basil plants cultivated under greenhouse conditions or in hydroponics produced lower RA amounts (Juliani et al. 2008, Nguyen et al. 2010, Kiferle et al. 2013).

Kiferle et al. (2011) reported that among the CADs of interest, RA is the only compound found in basil shoot cultures at relatively high amounts: $40-50 \mathrm{mg} \mathrm{g}^{-1}$ (d.m.). Our experiments confirm the remarkable presence of RA $\left[154.8 \mathrm{mg} \mathrm{g}^{-1}\right.$ (d.m.)] in plantlets grown in RITA $^{\mathrm{TM}}$ vessels exceeding by far the content reported in the literature for in vitro-grown sweet basil. For instance, the content of
RA is $0.18 \mathrm{mg} \mathrm{g}^{-1}$ (d.m.) in nodal explants grown in a plastic airlift bioreactor (Kintzios et al. 2004), $10 \mathrm{mg} \mathrm{g}^{-1}$ (d.m.) in suspension cultures (Kintzios et al. 2003), and $20 \mathrm{mg} \mathrm{g}^{-1}$ (d.m.) in immobilized cells (Moschopoulou and Kintzios 2011). Despite the high RA content detected in plantlets growing in RITA ${ }^{\mathrm{TM}}$ bioreactor, we observed that DO accumulated less RA than GE. On the contrary, other authors showed a higher RA production in DO in vitro (Kiferle et al. 2011) than in vivo (Nguyen et al., 2010). This red-leaved cultivar has been proven to accumulate a high amount of phenolics under greenhouse conditions with a more than double RA content as compared to other green-leaved sweet basil cultivars (Juliani et al. 2008). The different RA production of the two cultivars might be indeed related to the dissimilar evolution of ethylene and dry mass accumulation during the in vitro culture as observed in other plant tissue cultures (Mensuali-Sodi et al. 1989, Zhao et al. 2005). The stop of growth since the $14^{\text {th }}$ day and the large ethylene production may be the result of an earlier shift from primary to secondary metabolism in GE than in DO, suggesting a different metabolic activity in the two cultivars.

In conclusion, the composition of medium and the vessel micro-environment influenced growth, morphology, and secondary metabolism of the in vitro grown basil shoots. The results obtained with Magenta ${ }^{\mathrm{TM}}$, Microbox $\mathrm{ECO}_{2}{ }^{\mathrm{TM}}$, and $P C C V 25^{\mathrm{TM}}$ vessels suggest that photomixotrophic conditions coupled with positive $\mathrm{P}_{\mathrm{N}}$ values influenced explants growth without any significant effects on the RA production. The largest amount of dry mass was produced in Growtek ${ }^{\mathrm{TM}}$; this system maintained daily negative $\mathrm{P}_{\mathrm{N}}$ compensated by a facilitated sugar uptake from the medium. The poor growth and high RA content in the shoots cultured in RITA $^{\mathrm{TM}}$ system were likely the result of a combination of factors including the large accumulation of ethylene released from the plant tissues and entrapped in the headspace, the tissue hyperhydration, the transient nutrient starvation, and the negative $\mathrm{P}_{\mathrm{N}}$ values not compensated by an adequate sugar uptake.

The current study indicates that the RA production in the in vitro plants cultured in $R I T A^{\mathrm{TM}}$ bioreactor was up-regulated when low $\mathrm{P}_{\mathrm{N}}$ was associated to a reduction of the biomass production. Our work confirmed the close relationship between the environment of the in vitro culture (the vessel, culture medium, exchange of air, etc.) and the plantlet metabolism which, when suitably modified, can lead to an increased production of secondary metabolites.

\section{References}

Afreen, F., Zobayed, S.M.A., Kozai, T.: Photoautotrophic culture of Coffea arabusta somatic embryos: development of a bioreactor for large-scale plantlet conversion from cotyledonary embryos. - Ann. Bot. 90: 21-29, 2002.
Begum, F., Amin, M.N., Azad, M.A.K.: In vitro rapid clonal propagation of Ocimum basilicum L.. - Plant Cell Tissue Organ Cult. 12: 27-35, 2002.

Bertoli, A., Lucchesini, M., Mensuali-Sodi, A., Leonardi, M., 
Doveri, S., Magnabosco, A., Pistelli L.: Aroma characterisation and UV elicitation of purple basil from different plant tissue cultures. - Food Chem. 141: 776-787, 2013.

Biddington, N.L.: The influence of ethylene in plant tissue culture. - Plant Growth Regul. 11: 173-187, 1992.

Bourgaud, F., Gravot, A., Milesi, S., Gontier, E.: Production of plant secondary metabolites: a historical perspective. - Plant Sci. 161: 839-851, 2001.

Chakrabarty, D., Park, S.Y., Ali, M.B., Shin, K.S., Paek, K.Y.: Hyperhydricity in apple: ultrastuctural and physiological aspects. - Tree Physiol. 26: 377-388, 2005.

Chanemougasoundharam, A., Sarkar, D., Pandey, S.K., AlBiski, F., Helali, O., Minhas, J.S.: Culture tube closure-type affects potato plantlets growth and chlorophyll contents. Biol. Plant. 48: 7-11, 2004.

Cho, G.H., Kim, D.I., Pedersen, H., Chin, C.K.: Ethephon enhancement of secondary metabolite synthesis in plant cell cultures. - Biotech. Progr. 4: 184-188, 1988.

Deng, Z., Chu, J., Wang, Q., Wang, L.: Effect of different carbon sources on the accumulation of carbohydrate, nutrient absorption and the survival rate of Chinese Ash (Fraxinus mandshurica) explants in vitro. - Afr. J. agr. Res. 7: 3111-3119, 2012.

Dey, S.: Cost-effective mass cloning of plants in liquid media using a novel Growtek bioreactor. - In: Hvoslef-Eide, A.K., Preil W. (ed.): Liquid Culture Systems for in Vitro Plant Propagation. Pp. 127-141. Springer, Dordrecht 2005.

Diarra, S.T., He, J., Wang, J., Li J.: Ethylene treatment improves diosgenin accumulation in in vitro cultures of Dioscorea zingiberensis via up-regulation of CAS and HMGR gene expression. - Electron. J. Biotechn. 16: http://dx.doi.org/10.2225/vol16-issue5-fulltext-9, 2013.

Dias, M.C., Pinto, G.C., Correia, M., Moutinho-Pereira, J., Silva, S., Santos, C.: Photosynthetic parameters of Ulmus minor plantlets affected by irradiance during acclimatization. - Biol. Plant. 57: 33-40, 2013.

Fujiwara, K., Kozai, T., Watanabe, I.: Measurements of carbon dioxide gas concentration in stoppered vessels containing tissue cultured plantlets and estimates of net photosynthetic rate of the plantlets. - J. Agr. Meteorol. 43: 21-30, 1987.

Gaspar, T., Franck, T., Bisbis, B., Kevers, C., Jouve, L., Haussman, J.F., Dommes, J.: Concepts in plant stress physiology. Application to plant tissue cultures. - Plant Growth Regul. 37: 263-285, 2002.

Georgiev, M.I., Weber, J., Maciuk, A. : Bioprocessing of plant cell cultures for mass production of targeted compounds. Appl. Microbiol. Biotechnol. 83: 809-823, 2009.

Hakkim, F.L., Shankar, C.G., Girua, S.: Chemical composition and antioxidant property of holy basil (Ocimum sanctum L.) leaves, stems, and inflorescence and their in vitro callus cultures. - J. Agr. Food Chem. 55: 9109-9117, 2007.

Hazarika, B.N.: Morpho-physiological disorders in in vitro culture of plants. - Sci. Hort. 108: 105-120, 2006.

Ikemeyer, D., Barz, W.: Comparison of secondary product accumulation in photoautotrophic, photomixitrophic and heterotrophic Nicotiana tabacum cell suspension cultures. Plant Cell Rep. 8: 479-482, 1989.

Jackson, M. B.: Aeration stress in plant tissue cultures. - Bulg. J. Plant Physiol. 96 (Special Issue): 109, 2003.

Jayasinghe, C., Gotoh, N., Aoki, T., Wada, S.: Phenolics composition and antioxidant activity of sweet basil (Ocimum basilicum L.). - J. Agr. Food Chem. 51: $4442-$ 4449, 2003

Juliani, H.R., Koroch, A.R., Simon, J.E.: Basil: A new source of rosmarinic acid - In: Ho, C.T., Simon, J.E., Shahidi, F., Shao, Y. (ed.): Dietary Supplements. Pp. 129-143. American Chemical Society, Washington 2008.

Karuppusamy, S.: A review on trends in production of secondary metabolites from higher plants by in vitro tissue, organ and cell cultures. - J. med. Plants Res. 3: 1222-1239, 2009.

Kiferle, C., Lucchesini, M., Mensuali-Sodi, A., Maggini, R., Raffaelli, A., Pardossi A.: Rosmarinic acid content in basil plants grown in vitro and in hydroponic. - Cent. Eur. J. Biol. 6: 946-957, 2011

Kiferle, C., Maggini, R., Pardossi, A. Influence of nitrogen nutrition on growth and accumulation of rosmarinic acid in sweet basil (Ocimum basilicum L.) grown in hydroponic culture. - Aust. J. Crop Sci. 7: 321-327, 2013.

Kintzios, S., Kollias, H., Straitouris, E., Makri, O.: Scale-up micropropagation of sweet basil (Ocimum basilicum L.) in an airlift bioreactor and accumulation of rosmarinic acid. Biotechnol. Lett. 26: 521-523, 2004.

Kintzios, S., Makri, O., Panagiotopoulos, E., Scapeti, M.: In vitro rosmarinic acid accumulation in sweet basil (Ocimum basilicum L.). - Biotechnol. Lett. 25: 405-408, 2003.

Kobayashi, Y., Fukui, H., Tabata, M.: Effect of carbon dioxide and ethylene on berberine production and cell browning in Thalictrum minus cell cultures. - Plant Cell Rep. 9: 496-499, 1991a.

Kobayashi, Y., Hara, M., Fukui, H., Tabata, M.: The role of ethylene in berberine production by Thalictrum minus cell suspension cultures. - Phytochemistry 30: 3605-3609, $1991 b$.

Kozai, T.: Autotrophic micropropagation. - In: Bajaj, Y.P.S. (ed.): Biotechnology in Agriculture and Forestry: High Tech and Micropropagation I. Pp. 313-343. Springer-Verlag, Berlin - Heidelberg 1991.

Kozai, T., Kubota, C.: Concepts, definitions, ventilation methods, advantages and disadvantages. - In: Kozai T., Afreen, F., Zobayed, S.M.A. (ed.): Photoautotrophic (Sugar-Free Medium) Micropropagation as a New Propagation and Tansplant Production System. Pp. 9-30. Springer, Berlin 2005.

Kozai, T., Kubota, C., Chun, C., Afreen, F., Ohyama, K.: Necessity and concept of the closed transplant production system. - In: Kubota, C., Chun, C. (ed.): Proceedings for the International Symposium on Transplant Production in Closed System. Pp. 3-19. Kluwer Academic Publisher, Dordrecht 2000.

Lucchesini, M., Bertoli, A., Mensuali-Sodi, A., Pistelli, L.: Establishment of in vitro tissue cultures from Echinacea angustifolia D.C. adult plants for the production of phytochemical compounds. - Sci. Hort. 122: 484-490, 2009.

Lucchesini, M., Mensuali-Sodi, A.: Plant tissue culture-an opportunity for the production of nutraceuticals. - In: Giardi, M.T., Rea, G., Berra, B. (ed.): Bio-Farms for Nutraceuticals: Functional Food and Safety Control by Biosensor. Pp: 185-200. Springer, New York 2010.

Lucchesini, M., Mensuali-Sodi, A., Massai, R., Gucci, R.: Development of autotropy and tolerance to acclimatization of Myrtus communis transplant cultured in vitro under different aeration. - Biol. Plant. 44: 167-174, 2001.

Lucchesini, M., Monteforti, G., Mensuali-Sodi, A., Serra, G. Leaf ultrastructure, photosynthetic rate and growth of myrtle plantlets under different in vitro culture condictions. - Biol. Plant. 50: 161-168, 2006.

Makri, O., Kintzios, S.: Ocimum sp. (basil): botany, cultivation, pharmaceutical properties, and biotechnology. - J. Herbs 
Spices med. Plants 13: 123-150, 2007.

Martre, P., Lacan, D., Just, D., Teisson, C.: Physiological effects of temporary immersion on Hevea brasiliensis callus. - Plant Cell Tissue Organ Cult. 67: 25-35, 2001.

Matkowski, A.: Plant in vitro for the production of antioxidants, a review. - Biotech. Adv. 26: 548-560, 2008.

Mensuali-Sodi, A., Lucchesini, M., Maltinti, S., Serra, G., Tognoni, F.: Leaf senescence in tissue culture of Passiflora incarnata L.: the role of ethylene.- In: Ramina, A., Chang, C., Giovannoni, J., Klee, H., Perata, P., Woltering, E. (ed.): Advances in Plant Ethylene Research. Pp. 151-152. Springer, Dordrecht 2007.

Mensuali-Sodi, A., Panizza, M., Tognoni, F.: Studies on lavandin callus cultures: ethylene production in relation to the growth. - Biol. Plant. 31: 247-253, 1989.

Mensuali-Sodi, A., Panizza, M., Tognoni, F.: Quantification of ethylene losses in different container-seal systems and comparison of biotic and abiotic contributions to ethylene accumulation in cultured tissues. - Physiol. Plant. 84: 472476, 1992.

Mingozzi M, Morini S., Lucchesini M., Mensuali-Sodi A.: Effects of leaf soluble sugars content and net photosynthetic rate of quince donor shoots on subsequent morphogenesis in leaf explants. - Biol. Plant. 55: 237-242, 2011.

Morgan, P.W., Drew, M.C.: Ethylene and plant responses to stress. - Physiol. Plant. 100: 620-630, 1997.

Mosaleeyanon, K., Zobayed, S.M.A., Afreen, F., Kozai, T.: Relationships between net photosynthetic rate and secondary metabolite contents in St. John's wort. - Plant. Sci. 169: 523-537, 2005.

Moschopoulou, G., Kintzios, S.: Achievement of thousand-fold accumulation of rosmarinic acid in immobilized cells of sweet basil (Ocimum basilicum L.) by ten-fold increase of the volume of the immobilization matrix. - J. biol. Res. Thessalon. 15: 59-65, 2011.

Murashige, T., Skoog, F.: A revised medium for rapid growth and bioassays with tobacco tissue cultures. - Physiol. Plant. 15: 473-493, 1962.

Nguyen, P.M., Kwee, E.M., Niemeyer, E.D.: Potassium rate alters the antioxidant capacity and phenolic concentration of basil (Ocimum basilicum L.) leaves. - Food Chem. 23: 1235-1241, 2010.

Panizza, M., Mensuali-Sodi, A., Tognoni, F.: Role of ethylene in axillary shoot proliferation of lavandin-interaction with benzyladenine and polyamines. - J. exp. Bot. 44: 387-394, 1993.

Park, S.U., Uddin, M.R., Xu, H., Kim, Y.K., Lee, S.Y.: Biotechnological applications for rosmarinic acid production in plant. - Afr. J. Biotechnol. 7: 4959-4965, 2008.

Patnaik, J., Sahoo, S., Debata, B.K.: Somaclonal variation in cell suspension culture-derived regenerants of Cymbopogon martini (Roxb.) Wats var. motia. - Plant Breed. 118: 351354, 1999.

Petersen, M., Simmonds, M.S.J.: Molecules of interest: rosmarinic acid. - Phytochemistry 62: 121-125, 2003.

Pospíšilová, J., Haisel, D., Synková, H., Čatský, J.,Wilhelmová, N., Plzáková, Š., Procházková, D., Šrámek, F.: Photosynthetic pigments and gas exchange during ex vitro acclimation of tobacco plants as affected by $\mathrm{CO}_{2}$ supply and abscisic acid. - Plant Cell Tissue Organ Cult. 61: 125-133, 2000.

Rady, M.R., Nazif, N.M.: Rosmarinic acid content and RAPD analysis of in vitro regenerated basil (Ocimum basilicum L.) plants. - Fitoterapia 6: 525-533, 2005.

Saher, S., Piqueras, A., Hellin, E., Olmos, E.: Hyperhydricity in micropropagated carnation shoots: the role of oxidative stress. - Physiol. Plant. 120: 152-161, 2004.

Sahoo, Y., Patfnaik, S.K., Chand, P.K.: In vitro propagation of an aromatic medicinal herb Ocimum basilicum L. (sweet basil) by axillary shoot proliferation. - In vitro cell. dev. Biol. Plant. 33: 293-296, 1997.

Savio, L.E. B., Astarita, L.V., Santarém, E.R.: Secondary metabolism in micropropagated Hypericum perforatum $\mathrm{L}$. grown in non-aerated liquid medium. - Plant Cell Tissue Organ Cult. 108: 465-472, 2012.

Steyn, W.J., Wand, S.J.E., Holcroft, D.M., Jacobs, G.: Anthocyanins in vegetative tissues: a proposed unified function in photoprotection. - New Phytol. 55: 349-361, 2002.

Xiao, Y., Niu, G., Kozai, T.: Development and application of photoautotrophic micropropagation plant system. - Plant Cell Tissue Organ Cult. 105: 149-158, 2011.

Yasmin, S., Mensuali-Sodi, A., Perata, P., Pucciariello, C.: Ethylene influences in vitro regeneration frequency in the FR13A rice harbouring the SUB1A gene. - Plant Growth Regul. 72: 97-103, 2014.

Zhao, J., Davis, L.C., Verpoorte, R.: Elicitor signal transduction leading to production of plant secondary metabolites. Biotechnol. Adv. 23: 283-333, 2005.

Ziv, M.: Bioreactor technoloy for plant micropropagation. Hort. Rev. 24: 1-30, 2000.

Zobayed, S.M.A., Saxena, P.K.: Production of St. John's wort plants under controlled environment for maximizing biomass and secondary metabolites. - In vitro cell. dev. Biol. Plant. 40: 108-114, 2004. 